This item was submitted to Loughborough's Research Repository by the author.

Items in Figshare are protected by copyright, with all rights reserved, unless otherwise indicated.

\title{
Creating geographies of hope through film: performing space in Palestine- Israel
}

PLEASE CITE THE PUBLISHED VERSION

http://dx.doi.org/10.1111/j.1475-5661.2012.00546.x

PUBLISHER

Wiley / Article @ The Author. Journal @ Royal Geographical Society (with the Institute of British Geographers)

VERSION

AM (Accepted Manuscript)

LICENCE

CC BY-NC-ND 4.0

\section{REPOSITORY RECORD}

Mavroudi, Elizabeth. 2019. "Creating Geographies of Hope Through Film: Performing Space in Palestineisrael”. figshare. https://hdl.handle.net/2134/18168. 


\title{
Creating geographies of hope through film: performing space in Palestine-Israel
}

\author{
Abstract \\ This paper will explore the value and role of critical notions of space in the current \\ impasse in Palestine-Israel through a case study on two films and their creative use of \\ space. The main aim of the paper is to illustrate that it is useful for geographers to use \\ analyses of performance in order to theorise space in more hopeful ways, particularly in \\ areas of conflict, by stressing the importance of space as open-ended and performative. \\ Through a discussion of two films, one by Elia Suleiman and the other by Michel Khleifi \\ and Eyal Sivan, the paper argues that space, if imagined as dynamic, in-between, and \\ potentially connecting Palestinians and Israelis, can be transformative and have a \\ positive role to play in interrogating us/them relationships, power inequalities and \\ Othering in the region. The paper highlights the value of using third space and \\ performance to help create a spatial politics of affect, which may in turn lead to \\ changing perceptions of the Other in conflict regions. Therefore, the paper makes a \\ contribution, not only to the geographical literature on how space is appropriated, and \\ constructed in Palestine-Israel, but also to geographical work on hope, film and \\ performance.
}

Key words Palestine-Israel, hope, space, film, performance, connections 


\section{Introduction}

Analyses of Palestine and Israel often privilege one 'group', 'identity' or 'place' over the other rather than attempting to theorise and examine potential connections. As a result, space is often theorised in negative ways, as disconnecting and separating Palestinians and Israelis and as disempowering and marginalising for Palestinians. In turn, the concept of space becomes one which becomes closed to alternative, more positive imaginings and theorisations of how space can connect Palestinians and Israelis and potentially help create hope, shared identities, trust, and conflict resolution. In areas of conflict, film and theatre performances can be a powerful tool in this endeavour because they may use and interrogate space in more radical, malleable ways, in order to try and imagine hope, peaceful alternatives, or to encourage communication and connection between rival sides.

This paper highlights the transformative nature of space, made possible through the analysis of performance. In particular, film, with its powerful visual, emotional, affective potential, provides a useful case study. There is a need to move beyond arbitrary binaries between the 'reel' and the 'real' (Dixon and Grimes 2004) by borrowing the notion of 'third space' from Bhabha (2004) and by stressing performative articulations of space, that move beyond representation and borders towards a politics of affect (Thrift 2004). This paper has two main aims. Firstly, it argues that analyses of how space is actively constructed, manipulated and performed within film can help geographers to theorise space in more positive, hopeful ways in conflict situations. Secondly, it points out that such performances can in turn have more material 
repercussions by creating social and political change in conflict areas, because of alternative imaginings and uses of space.

The paper highlights that within film, third space becomes open-ended, both connected and separated from both the 'real' and the 'reel'. As a result, this can allow alternative, innovative, radical understandings of space to emerge, in which people and places are linked in surprising, messy and emotional ways; in conflict areas, such imaginings can play an important role in helping geographers to theorise space in potentially more positive, connecting, hopeful ways, and as moving beyond representations and boundaries, towards a spatial politics of affect. Therefore, through an analysis of space within two films, one by Elia Suleiman and the other by Michel Khleifi and Eyal Sivan, this paper engages with, and adds to, the geographical literature on Palestine-Israel, film, hope and the more-than-representational, stressing that a hopeful politics of affect within conflict areas is possible. The two films the paper focuses on are The Time That Remains (Elia Suleiman) and Route 181: Fragments of a Journey to Palestine-Israel (Michel Khleifi and Eyal Sivan). The film-makers actively deal with notions of space, place and time in their films; although the former is a semifictitious film and the latter a documentary, both highlight the ambivalent, difficult yet important role of space in the region. They implicitly also deal with the issue of hope and portray hopefulness in surprising, yet potentially empowering ways.

A 2009 UK/French/Belgian/Italian production, The Time that Remains received detailed (and largely positive) reviews in the UK (in the Guardian on $27^{\text {th }}$ May, New Statesman on $28^{\text {th }}$ May 2010 and Observer on $30^{\text {th }}$ May 2010) after it was shown at the London Palestine Film Festival. In the Middle East it was reviewed by the Electronic 
Intifada on $9^{\text {th }}$ May where it was called a 'masterpiece'. In Israel, Haaretz interviewed Elia Suleiman in Cannes and a detailed and very positive review of the film appeared in February 2010. A 2003 documentary film, Route 181 was made jointly by a Palestinian (Khleifi) and an Israeli filmmaker (Sivan). A Belgian/French/UK production, Route 181

also received positive reviews in the Electronic Intifada on $13^{\text {th }}$ June 2004 but has had fewer reviews than The Time that Remains. It is also worth noting that numerous film festivals in the West actively promoting Palestinian film have played an important role in advertising such films and bringing them to the attention of critics and audiences. The two films were chosen because they deal with similar issues but in different ways; both explore Palestinian-Israeli interaction and the difficulties and opportunities this poses.

\section{Being, becoming, hoping: the geographies of hopeful spaces}

Theorisations on Palestine-Israel have often 'taken sides' in the sense that they are written from one or the other perspective and those that deal with both tend to focus on the negative repercussions of power inequalities. Whilst the latter is very important and relevant, it is also important to consider and utilize more hopeful conceptualisations about the region. A focus on Palestine-Israel does not suggest an easy, unproblematised merging of Palestine and Israel but a commitment to consider the potential of shared space, place and time which, whilst acknowledging the materialities of inequality, also recognises the potential of hope and creative articulations of spatial interactions, jarrings and performance. The focus on negative separations and violent conflicts can make thinking hopefully about the region difficult. Despite the excellent 
work that has been conducted in geography and beyond it, there is potential for critical conceptualisations that focus on the symbolic, material, virtual, performative and imagined ways in which borders are transgressed, connections forged and lives and identities shared. In order to do this, the paper brings together three quite distinct areas of literature: geographical work (and beyond) on Palestine-Israel (and in particular, research stressing connections and sharing between Palestinians and Israelis), geographies of hope, affect and performativity and the geographies of film. In turn, it hopes to highlight the value of such an approach to help create more hopeful, affective geographies in conflict situations, which focus more on the sharing and connectedness of space.

Numerous scholars in geography and beyond have debated the complex issues that exist in the region. These include analysis on the contested historical context and the political and territorial wrangling over land (Newman 2006, 2008; Schnell 2001; Yiftachel 2006) from the creation of the state of Israel in 1948, which Palestinians call 'The Nakba' (or catastrophe), and the contested events leading up to it as well as the subsequent ordering and controlling of land by Israel (Falah 2003). Such divisions occurred, for example, in 1967 and the Six Day War and after the Oslo Accords in 1993 and 1995, which has caused fragmentation in the West Bank and resistance strategies in the Palestinians territories as evidenced by the two Palestinian Intifadas as well as the contested 'peace process' (Said 2001). In turn, this has created a complex and power-laden landscape, where geographies of difference, separation and connection are negotiated and where boundaries are affected by obstacles such as the 'separation wall' and Palestinian attempts to get on with daily lives by adapting to a changing and 
increasingly restrictive network of Israeli checkpoints, surveillance and control (Graham 2002; Taraki 2006; Zureik et al 2010). As a result, scholars have analysed space and place in relation to power relations, colonialism, borders and history (Gregory 2004; Long 2006, 2009; Harker 2006; Hanafi 2009) as well as in relation to the built environment (Yacobi 2008a). All raise relevant points, stressing the current inequality, injustice and oppression that exists and have an important role to play in highlighting the problems in the region. They also provide excellent discussions on the background issues that are analysed in this paper. Whilst acknowledging uneven power relations, it is important not to create dichotomies between Israelis and Palestinians and to recognise that there are inclusions, exclusions and power relations within and between communities. Despite the strong and relevant nature of such research, space in the region is often conceptualised as divided and separate; it is constrained into categories of us and them and does often not necessarily allow for more critical engagements with space that imagine and construct Palestinians and Israelis as connected.

There are useful insights into such a process of connection beyond geography. Research on conflict resolution, reconciliation (Shamir and Shikari 2002; Kuriansky 2007; Maoz 2011), co-existence (Stephan et al 2004), peace education (Schulz 2008; Menkel-Meadow and Nutenko 2009), shared identities and cultures (Abramovitch 2005), activism (Powers 2006; Pallister-Wilkins 2009; Hallward 2009), shared scholarship (Scham 2000; Kayyal 2006) and histories (Pappé 2004) has hinted at more hopeful futures by focusing on potential connections, communications and the building of trust in material ways. The potentially connected nature of Palestinians and Jews in the region has been particularly emphasised within cultural analysis (Gur-Ze'ev and Pappé 2003; 
Brenner 2003; Abdel-Malek 2006) and by those who support Jews and Palestinians living together in one state or the so-called one-state solution (Tilley 2005; Abunimah 2006; Mavroudi 2010).

Particularly relevant for this article is work that focuses on theatre, performance and peace education as a means to break down barriers between Jews and Palestinians in order to engage with the Other. There is a history of such theatre in the region, for example, in so-called alternative theatre (Yerushalmi 2007; Ben Zvi 2006). In such drama, performative space is both suspended and subverted, to allow for alternative meanings and potential transformation because of the insistence on multiple voices and a refusal to accept dominant and totalizing discourses of the Other, engaging their audience in critical thinking about the conflict and Jewish-Palestinian relations. Gesser-Edelsburg (2011), for example, highlights the important role that Israeli theatre that deals with the conflict can play in creating social change and peace education, through so-called 'edutainment', as well as the challenges of creating such potentially radical theatre aimed at changing people's perceptions. Ultimately, he feels that theatre must do more to give audiences the tools with which to create changes. However, others such as Urian (2004, cited in Gesser-Edelsburg 2011), Fenigstein (2007) and Walsh et al (2007) stress that performances can help audiences critique and contest what they see and experience and this can then translate into socio-political change.

There has also been an engagement with the transformative nature of theatre performance in geography, for example, through forum or community theatre, as geographers seek to re-materialise theatre with people and set it within its socio-cultural 
and political contexts. For example, Pratt and Johnston (2007) discuss forum theatre, and the politics of performance, in North America and its repercussions on spaces of politics, communication and democracy. Other geographers such as Nagar (2002) and Blunt et al (2007) have also sought to analyse the relationships between theatre and geography using case studies that highlight the role of people involved, suggesting that performance can use space in interesting, potentially transformative, hopeful ways.

Geographers have engaged explicitly with geographies of hope and fear in relation, for example, to spaces of hope (Anderson 2006; Anderson and Fenton 2008; Phillips 2009) and have explored the need for hopeful geographies that address material situations (Lawson 2007) as well as more theoretical concerns with the geographies of affect. As Lawson $(2007,336)$ stresses: "Geography has all the tools to open up space for alternative, hopeful visions of social, ecological, and political life." Her optimism is matched by other geographers who stress the need for geographical research to engage in radical research that "takes risks and imagines transitions" (Blomley 2007, 56). Anderson (2006) has written about the need to engage with the politics of possibility in a world that despite difficult and problematic is still in the process of becoming. This latency arguably provides space for hope. At the same time, writing about hope requires a material commitment to social and spatial justice. As identities, politics and bodies are performed within spaces, it is perhaps important to ask how geographers can imagine and conceptualise spaces in more malleable ways as dynamic, emotional and hopeful performances.

In order to imagine and realise hopeful futures and geographies, geographers have conceptualised space as beyond representation, generalisation, control and 
quantification (Thrift and Dewsbury 2000); as a result, dynamic everyday moments and performances are stressed. Performance is seen as elusive, resisting dichotomies, metanarratives and attempts at definition. The focus is on the 'doing' in everyday life, the actual practices that constitute continuous moments of performance. Thus, everyday life is seen as constantly 'becoming' or 'spacing (Crouch 2003). As a result, space becomes open-ended, fluid and dynamic, both grounded and connected to other times, places and spaces. One can then conceptualise space as in-between and, in the process, it can become enabling and politically empowering. Engaging in a 'politics of the moment' can shed light on the ways in which space forms part of daily life in perhaps surprising, messy and awkward ways. Thrift and Dewsbury (2000, 422, citing Phelan 1999, 224) also point out that "performativity is then this in-between-ness: "a space we might call the tension of the present time'"'. Such a moment is one that is cross-cutting, is in the process of becoming and evades closure, producing a spatial politics of affect, where boundaries are transgressed as connection and in-betweenness is emphasised. Such border crossings which stress the potentially empowering but also difficult aspects of colonial/postcolonial interactions (Bhabha 1994) and us/them, here/there relations (Anzaldúa 1987; Clifford 1997; Hall 1999) allow us to acknowledge but also move beyond dichotomies, disconnections and power relations and stress the complex nature of hybridity and of third space.

One can argue that there is a need to conceptualise lives, identities and spaces as connected and transgressing borders, however difficult this may be, because the 'inbetween' can be seen as an enigmatic and potentially liberating space. Although the notions of border crossings, and liminal, hybrid, third space are, far from new (see 
Bhabha 1994, for example) and continue to be theorised and critiqued (see Kalra et al 2007; Hutynk 2005; Mitchell 1997), this paper argues that a conceptualisation of third space, hope and performativity through an analysis of film, is a fruitful one. Such an approach stresses that the active process of spacing within and between the 'reel' and the 'real' is one that can be political, potentially hopeful, and insists on articulations of space that are elusive, subversive, affective, as well as grounded, fostering alternative imaginings and materialities of space and connection between people in conflict areas. This stresses the potential of such liminal, third space or a performative, spatial politics of hope. It is through film, perhaps, that the most powerful evocation and articulation of this can be seen, because of such real-reel relationships, the juxtaposition of materiality and imagination and the ability to use space in innovative ways, which in turn may create social and political change.

Geographers have discussed relationships between film and space (see Cresswell and Dixon 2002), drawing attention to factors such reel-real relations, representation, spectacle and narrative (Aitken and Zonn 1994; Cresswell and Dixon 2002). Lukinbeal $(2004,248)$, for example, has stressed that social and cultural meanings are constructed and contested through film and television, highlighting their value to geographical analyses of society, culture and politics. Therefore, one might argue that an analysis of film has an important affective, political role to play. There has been a move from depicting films as visual representations of society, geopolitics and everyday relations, towards examining films as affective, emotional performances which move beyond and defy representations. Geographers, therefore, have a useful role to play in analysing the politics of affect through film, focusing, for example, on geopolitics 
and the powerful role that film can play in deconstructing geopolitical power relations (Carter and McCormick 2006; Dodds 2003). Analysing space within film as performance rather than representation can help transform space, from a politics of representation to a politics of affect, where third space is open-ended, dynamic and active, moving beyond and between dichotomies and boundaries. Therefore, one could argue that there is scope for more geographical work on the potentially transformative nature of film, through a focus on the third space that exists in-between the 'real' and the 'reel' as a space of possibility, and of hope, particularly in conflict situations. This in turn allows for the theorisation of space within film to be connected to the materiality of everyday life, and in doing so, forces connections and synergies between different sides, and encourages geographical conceptualisations of space in more positive ways in regions such as Palestine-Israel.

\section{Performing hopeful space in Palestine-Israel through film?}

Ashcroft (2009) has written persuasively on the viability of hope in Palestine-Israel. Using the work of Said, he discusses how negotiations of identity and space as unhinged and suspended can become hopeful:

But what if the idea of identity as unresolved, destabilizing and constantly protean rather than fixed and imprisoning, is itself a form of utopianism, a recognition of hope? ... The freedom from borders is itself a deeply paradoxical freedom, for it entails immense risk, it means disembarking from 
the comfort of Identity, and perhaps the comfort of home, for the much more stormy waters of becoming ...

Here, becoming is conceptualized as identity-in-the-making, a constant process that is placed within everyday life, in which borders are transgressed and space is used in hopeful ways. Such a focus is important for the region because it stresses the need to move beyond conceptualisations of space as compartmentalised, carved up and static, which do not allow for more open-ended, positive notions of space, identity and belonging.

One useful way to analyse space in more positive, fluid ways is through films that deal with Palestine-Israel. According to Gertz and Khleifi (2008) from the 1980s onwards, Palestinian films have become more elusive and have addressed issues of difference, diversity and the difficulties of living through violence, divisions, and tensions. Alexander (2005) has highlighted the hybrid nature of Palestinian film production, caught in-between nationalism and diaspora and the creation of films that are often exilic and free from a nation-building project, but are also intimately connected to articulations of Palestinian-ness. Palestinian (and Israeli) film-makers have increasingly started to deal with space, identity and politics in imaginative ways that are more open-ended, critical and questioning (Gertz and Khleifi 2008; Shohat 1989). Many of these films and documentaries are concerned with the everyday, the mundane, but also the surreal and the supernatural. They may deal with intense, powerful issues in a playful, ironic manner that fragments and deconstructs issues. Above all, many of these 
films engage the imagination and use symbolism, creativity and art to imagine alternative worlds and spaces that may be cut off in reality.

Moments and spaces become fluid and malleable, allowing hopes, dreams, oppressions and so forth to become enacted and dealt with through the tension inbetween being and becoming, and between the 'real' and the 'reel'. The notion of an affective third space can help conceptualise embodied and in-between moments which, through their liminality, can become an empowering politics of affect, as categories such as us and them, here and there, past, present and future, the national, and the diasporic become dismantled. At the same time, however, there are those who point to the more limited nature of liminality and border crossings; according to Bardenstein (2005), for example, hybridity within Palestinian and Israeli cinema is not necessarily transformative.

There appears to be an obsession with space in Palestinian films (Gertz and Khleifi 2008). For example, Khleifi's films often seem to suggest an open landscape in which borders are transgressed but within which place is still important as an everyday, lived concept that holds meaning for people; however, it is within Suleiman's films that a complete dispersal with borders and roots can be seen. Suleiman's films perform a Palestine that is not rooted in any landscape or place. His films therefore question the very nature of territorial based nationalism, and although they are films about Palestinians, they often lack an identifiable Palestinian thread. His films stress the need for a post-national Palestine, in which Palestinian identities are one of many in the landscape. He does not represent identities, but rather lets them unfold on the screen. The 'letting go' of images, voices and experiences is one example of how identities can 
be performed in a non-representational, non-judgmental, yet thought-provoking manner that can allows a conceptualisation of how space, rather than being constrained for narrowly defined constructions of nationalism, can become open-ended and allow identities and belonging to be negotiated in more shared and inclusive ways.

\section{Elia Suleiman's The Time that Remains}

Born in Nazareth in 1960, Elia Suleiman has been hailed as one of the leading Palestinian filmmakers, able to portray the 'frivolity' and 'absurdity' of Palestinian-Israeli relations (Dabashi 2006) and whose films, through their comic moments, are able to imagine hopeful futures. The third spaces he creates (Gertz and Khleifi 2008) open up what he calls "multiple spaces that lend themselves to different readings" (Erikson 2003, 98 cited in Gertz and Khleifi 2008, 172). His films often seem fragmented, yet what emerges is often a disjointed whole in which there may be no 'truths' but in which space and time are elevated to show their elusive importance to the region. He has made seven films, ranging from Introduction to the end of an Argument in 1990 to The Time that Remains in 2009. For example, in one of Suleiman's most well-known films, Divine Interventions (2002), a balloon with Arafat's face on sails over Israeli soldiers and the 'separation wall' which is being built between Israel and the West Bank (for more on the building of the wall see Bowman 2007); the director enacts this tension between being and becoming through humour and satire; the balloon is soaring over the Wall, many Palestinians cannot. Space becomes conceptualised as a utopian, political, hopeful vision, a playful yet bittersweet form of connection and border transgression. 
Suleiman's more recent film, The Time that Remains: Chronicle of a Present Absentee is advertised as semi-autobiographical. Suleiman engages with space in radical, surprising and elusive ways in his films; in the process, he 'frees' up liminal space. The title and sub-title of the film stress the importance of both time and space. It suggests that no time remains, so there is a feeling of hopelessness, a sense of urgency but at the same time, it stresses that there is a need to act in the time remaining. In this way, the title and film problematise accepted notions of space and time and make a political point about the situation in the region. The word 'present absentee' refers to those Palestinians who remained in Israel after 1948; it is an ambivalent word and outlines their complex and position (for more on this group see Rabinowitz and Abu-Baker 2005). At the London Palestine Film Festival in 2011, Suleiman discussed, in a $\mathrm{Q}$ and $\mathrm{A}$ session, what he called linear and vertical time as well as the poetics of space. Linear time he saw as time that is imposed upon us by societal norms and expectations and vertical time is time that we ourselves create and make possible. In the same way, what he called the 'poetics of space and humour' suggests alternative space in which freedom and hope is a possibility but which exists alongside despair and apathy. The next section will go onto to analyse the detailed ways in which this is achieved in the film.

The careful and precise way in which Suleiman frames his shots stresses the poetics of space as a carved out space in which the present becomes heightened. Space becomes stretched, and the focal point of the screen. Silence is also a tool used to create this. Suleiman's lead character is someone called E.S, who also appears in his earlier film, Divine Intervention. The anonymisation and silence of this character could 
be seen as a politicised comment on the Palestinian people and their position within the region. However, it can also be seen as a way to free space from distraction and to stress the importance of space in the future of the region. This space, awkward and difficult though it may be, still holds promise for peace, but it needs to be freed from preconceptions, assumptions and representations. It becomes a performative tool in which space is used in order to provide pause for thought and reflection. Suleiman is spacing the region, forcing us move to different rhythms, and improvise in particular liminal times and spaces. Suleiman also uses time in very noticeable ways; he reminds us of the repetition, the very noticeable, mundane-ness of daily life. He also keeps reminding us of the situation in the region but, at the same time, the fact that characters have to deal with things again and again, but in slightly different ways, also inadvertently manipulates time and creates possibilities through repetition. This juxtaposition is reminiscent of Bhabha's work (1994) on the link between the colonial and the postcolonial where the colonised gain power by awkward, almost-repetition of the coloniser. This forces spaces of hope to appear, in which the present is viewed through the past and, in the process, what appears is always part of something else. Such obscurity suggests both hidden silences and the need for reflective clarity. As an emotion, hope is enacted when there is the potential for clarity as it stresses the connections between the tangible and the intangible. Therefore, to become hopeful through and within such space requires a commitment to connection and recognition that although moments in films may be conceptualised as representations, it is more fruitful to see them as dynamic and non-representational performances. In this way, moments can become political opportunities for transcending accepted norms and ways of seeing, creating a 
spatial politics of affect. Obscurity and juxtaposition can lead to a vision for change, whilst at the same time, reminds us that there will always be hidden injustices and oppressions that need to be overcome.

At the beginning and at the end of The Time that Remains, there is a taxi driver who gets lost in a rain storm, with a figure in the background who does not talk at the beginning but reveals himself as E.S at the end. At the beginning he sits there like a ghostly figure in the back watching over the Israeli taxi driver who is talking to him and getting frustrated at the fact that he is lost and cannot contact his colleagues on the radio. There is fog, rain, and obscurity and this leads us to question whether the future is bleak and silent for Palestinians. The future may be bleak but is also suggestive of change and possibility if one can make sense of the haze; however, the future is not necessarily visible or clearly mapped out yet and it is within third spaces that hope may appear, as we are asked to question the status quo in light of the past and future. Elsewhere too, tense situations between Israelis and Palestinians appear but at the same time, hope appears in unexpected moments such as when Suleiman's father saves the life of an Israeli soldier, highlighting the need for connections, even in difficult situations. A more ambivalent, yet intensely funny incident involves a very large military tank outside a Palestinian home; the Palestinian is chatting away animatedly on his mobile phone, walking backwards and forwards with the barrel of the tank following his every slight move. Then the man goes inside and the barrel 'finds' E.S who is hiding behind a wall watching the whole thing in disbelief. Despite being a wry observation of power inequalities, the whole scene presents spaces of possibility and opportunity where Palestinians go about their daily lives despite the difficulties present (Taraki 
2006; Makdisi 2008), a common observance that also appears in Khleifi and Sivan's film below. E.S's fear highlights the dangers involved but ultimately the comedy of the situation forces a re-thinking of how power relations are negotiated in daily spaces and the ways in which us/them relationships can be subversive.

The film emphasises the value of third space as its in-between-ness stresses the need to unpack how identities, us/them relationships and Othering are negotiated in material and symbolic ways. Said (1978) and Portugali (1993), for example, remind us that identities can be seen as mirror images; we define ourselves in relation to others and in doing so we mediate difference as we subvert and consume the Other. The film demonstrates how this process can be both empowering and difficult. Such subversion of power and domination can also be seen in the suggestions that appear throughout the film that Israeli soldiers are only trying half heartedly to do their job; for example, there are fishing incidents throughout the film that show this, where the soldiers put a spotlight on Elia's father and a friend and ask them where they are from, if they have their IDs but do not bother to check anything. Soldiers are often depicted as both brutal and comical in the film, and this appears to occur more and more as the time in the film progresses, a comment perhaps on the absurdity of the situation. For example, there is a 1948 incident with soldier who was tying his father's arms and was trying to put a bag over his head but could not reach because he was too short and so got a rock and stood on the rock but was unsuccessful in the end; such a gruesome image was tempered by the soldier's inability to do his job and suggests the ridiculousness of depressing events that have occurred and keep occurring in the region. An even more surreal moment appears when E.S faces the 'separation wall' (which is again a topic 
that Khleifi and Sivan also deal with in their film). E.S faces the wall, takes a pole vault and then soars over it: this is a political statement but is also slightly comical and suggests the malleability and pointlessness of enforced barriers. The physical wall becomes obsolete, a symbol and reality of separation (Usher 2006) but also one that can and should be transgressed and can become linked to Palestinian agency (Shalhoub-Kevorkian 2006) and activism (Pallister-Wilkins 2009; Gordon 2010). Such third space creates potentially enabling moments that allow alterative imaginings that are both idealistic but at the same time, grounded in material circumstances that require critical attention.

One of the final scenes of the film involves a club in Ramallah, in which soldiers and young Arabs are in a club listening to loud music, having a good time. The soldiers with a loudspeaker suddenly tell them that there is a curfew on; they tell them again and again, but are not heard by the young people and then, as the soldiers are in the process of telling them, they themselves start nodding their heads in time to the music. Here is a clear statement about the possibility of the two 'sides' somehow being in tune with eachother, dancing differently but to the same music. The ending music, a funky remix of 'Staying Alive' is a lively, almost cynical version of the original and hints at the reality of a difficult situation but one in which there is a glimpse of hope. Again its brash sound is almost jarring and uncomfortable, yet is also enjoyable and upbeat. The film illustrates how despite difficulties, constraints and tensions, third space can become a positive force and can inspire imagined connections, whilst recognising that there are also disconnections and a lack of communication. It performs the complexities and the 
hopes of the region by forcing together difficult and often jarring issues, times, identities and places in tangible and intangible ways.

Michel Khleifi and Eyal Sivan's Route 181: Fragments of a journey to Palestine-Israel

According to the Electronic Intifada website:

"Route 181 is the result of Khleifi and Sivan's two month journey from the south to the north of their country of birth -- they traced their trajectory on a map and called it Route 181. This virtual line follows the borders outlined in Resolution 181, which was adopted by the United Nations on November 29th 1947 to partition Palestine into two states. As they travel along this route, they meet women and men, Israeli and Palestinian, young and old, civilians and soldiers, filming them in their everyday lives."

Khleifi is well-known for his films that deal with memory, daily life, borders and place. His films often question Palestinian society's image of homogeneity and harmony and instead portray the inevitable tensions and clashes that exist and his later films such as Wedding in Galilee (1987) focus particularly on the 'blocking of space' (Gurtz and Khleifi 2008). Sivan is an Israeli filmmaker who has tackled difficult issues in films such as The Specialist in 1999 (Raz 2005) and has made 12 films so far.

The film runs for four and a half hours and is divided into three parts: South, Centre and North: they start from the South, from the port city of Ashdod in Israel, 
proceed to the frontiers of the Gaza Strip; then they go to the Centre, from the JewishArab city of Lydda/Lod to Jerusalem; and then finally to the North, from Rosh Ha'ayn, near the 'separation wall', to the Lebanese border. Its length allows the two filmmakers to spend a great deal of time on visual shots of land, houses and people, allowing them ample space to express themselves. Much of the film appears to be a comment on how space is utilised by Palestinians and Israelis and the conflicts, identities and opinions it creates. As a documentary its strength lies in its simplicity, and how it allows voices to appear in what seems to be a fairly non-edited fashion. The result is a film in which hopeful futures appear in glimpses through the words of people as they imagine peace or as they get on with daily life despite difficulties they face. At the same time, it presents bitter, resentful, angry Palestinian and Israeli voices too, people who are fed up and who portray hatred for the Other. Showing many different views and experiences and a lack of a voice-over allows the audience to delve into the complexities of contemporary and historical Palestine-Israel and to make up their own minds. However, it is a film that is ultimately uplifting because of its insistence on shared perspectives, histories and futures:

Their [the filmmakers'] sole political claim is that only through a joint journey of discovery and exposition-a route in common-can those elements of the future be found. The logic of the film is, therefore, essentially emancipatory. Khleifi and Sivan travel back through the present to a repressed and fragmented past only in order to be propelled forward again to a potential future (Abu-Manneh 2004, 46) 
The film presents spaces of everyday life and work as the directors make their way along the road, filming as they go along. This journey is one that symbolises the need to move forward; hence, the constant shots of both the road and the map lying on the dashboard of the car are reminders that the region needs to move forward and listen to those involved but also to use space in positive ways, to potentially create peaceful coexistence. There is, therefore, a sense of movement, of a journey through different people's lives and the spaces they inhabit. Such movement through space can denote a hopeful feeling of optimism despite the difficulties and stasis that is encountered along the way. For example, the directors are prohibited from moving through a checkpoint in Ramallah which at the time of filming was under curfew and control by the Israeli military and there are other examples of checkpoints that limit Palestinian movement. Therefore, the film constantly reminds the audience that such movement is juxtaposed with closure and an inability to transgress borders and that boundaries are continuously being created and dismantled. Maps are also an important aspect of the film and they are used extensively in practical and symbolic ways to stress the realities 'on the ground' and to link the present with the past (for more on the use of maps in the region see Wallach 2011). For example, maps are used to remind viewers of the UN partition plan of 1947, the places and names of pre 1948 Arab villages, the 'separation wall' and the shifting borders between Israelis and Palestinians.

Although the film is a journey through contemporary Palestine-Israel, it constantly travels into the past as people provide intimate oral histories and emotional memories, which are often seen as important (Masalha 2008). The past appears in many scenes, 
often haunting the present; in several scenes, for example, the portrait of Theodore Herzl (often seen as the founder of modern Zionism; for more on Zionism see Abdo and Yuval-Davis 1995 and Yuval-Davis 2007) appears as a reminder of 1948 and in other scenes, history and 'truth' is evoked and explained from Israeli and Palestinian perspectives. For example, a woman who had to leave Israel in 1948 and now lives in the West Bank remembers the actual (and painful) process of leaving her home and not being able to return. Edward Said (1986) has written persuasively about the complex role of memory and belonging for Palestinians in the region; however, it is important to appreciate the difficulties involved in negotiating different time-spaces and identity for Israelis as well. For example, in another scene, an Israeli man is trying to ensure that Arab names get remembered by trying to turning a former Arab home into an art gallery and keeping what he perceives to be the original name of 'Khirbet Naim' after the family who used to live there. He stresses the need to think of the future, not the past but also questions how in reality Jews and Palestinians could live together.

Therefore, such films highlight the importance of situating the past within the present and the complex ways the past is materialised in contemporary spaces, identities and everyday lives. Again, the concept of third space is useful as it reminds us of the need for connection, however difficult this may be, between moments of oppression and injustice and empowerment and resistance. Being and becoming hopeful requires discussion and communication even though there will always be material difficulties as people negotiate representations and realities around them. The value of this film is its insistence on dynamic performance rather than static representation; although it may seem that it is presenting the 'truth' it actually refutes 
meta-narratives and concentrates on moments and spaces that are both suspended above and placed within a time frame that although dynamic, also allows one to pause and reflect on what could be. As an emotional journey through and within space, the film provides unpolished, unglossy, sometimes confusing and ambivalent versions and visions of everyday life and perceptions. As ordinary people in the film speak from homes, streets, front yards, cafes, museums, and construction sites, the spatial entanglements of nation and state become apparent. They feel both trapped and liberated by space, which becomes an in-between space both problematic and potentially empowering. In this way, space creates vulnerability and agency, inclusion and exclusion.

Scholars have also outlined how space has become marked, (re)named, and a geopolitical tool for control (for example, see Falah 2003; Forman and Kedar 2004). For Israelis and Palestinians, identities and us/them relationships are practiced and negotiated in spaces but this can produce compromise as well as Othering. In a shop, an Israeli of Iraqi origin has a somewhat sympathetic view of Palestinians and says he would have happily lived with 'them' (Palestinians); he quietly hopes for peace. An Israeli man in the North of Israel also stresses the need for peace; he would ideally like to see a "peaceful multicultural state as long as no one side has all the power". However, in a cafe in Southern Israel with numerous images of 1948 'victory' on the wall, an Israeli lady talks of pride and of hatred and an inability to live together with Palestinians whom she calls a 'cancer' that she wants out of Israel; in the Negev Museum of Water and Security, a guide is adamant and stuck in his pro-Israeli opinions. His anger with the questions that are being asked of him demonstrates how emotional 
the situation is and how emotions and at times irrational thoughts and uses of space can interfere with peace.

Negotiations of self and identity in such spaces can therefore become problematic. Rather than being a passive backdrop, space becomes actively fought over and saturated with power and tensions between different conceptions of its use and role. For example, an elderly Jewish lady originally from Iraq in the mixed ArabJewish town of Lydda/Lod (in Israel) laments how Jews are moving out of her neighbourhood because it is becoming more 'Arab'. Her neighbour, who is such an 'Arab', complains about how Arabs are treated in Israel, feels that they lack basic rights and is bitter about demolition orders that threaten to remove an extension she has built for her brother who is homeless; she emphasises that she will "never leave; they'll have to kill me first". A council meeting in the same town reveals tensions between the majority Jewish councillors and the sole Arab one who has to defend illegal buildings by Arabs many of whom feel they have no choice but to build such houses because it is difficult to do so legally. This micro-space of contestation and negotiation is one that is finally mediated by the Chair of the meeting who pleas with both sides not to resort to extremism. Such mixed towns have been seen as potential spaces for co-existence (Herzog 2009) but at the same time, there is segregation and a lack of trust (see Falah et al 2008; Monterescu and Rabinowitz 2007), highlighting the often difficult position that Palestinian Arab citizens of Israel find themselves in.

The use of official space was also present at an immigration centre in Lod/Lydda where Jews from Ethiopia were being 'welcomed' and encouraged to integrate into Israel. This time, rather than being an arena of confrontation, the space was heavily 
laden with insider/outsider relationships and the power of a state to prescribe and assign national identities onto immigrants who rather than seeming overjoyed, looked distinctly out of place and uncomfortable with the speeches, acts and the accordion playing. At the end of the film, the filmmakers talk to Moroccan and Tunisian Jews who clearly would rather not be in Israel; one feels Moroccan Jews were 'hoodwinked' into coming to Israel with 'false promises that were paper thin'. This highlights the difficult job that a diverse and dynamic Israel has in imagining and practicing national unity that is based more on particular versions of 'Jewishness' than on pluralism and can make integration difficult (Ben-Eliezer 2007; Yacobi 2008b), even for Jews. Official, formal spaces can therefore become venues for silence and miscommunication as well as communication and negotiation in which power permeates and is both confronted and accepted. The many border scenes that appear are also examples of semi-official and often militarised space in which Israeli soldiers are in charge of a border that is unclear and in which space is controlled and monitored as much as possible. In one scene, a soldier says that there is no international border; he is then asked why. He responds that there's no state. He is then asked 'What's Israel'? and then responds saying 'No, there's no Palestinian state'. In another scene, an Israeli man points out how the Israeli army fells trees to feel safer and remembers how before 1967 there was no 'fence' between Israel and Gaza. Another example concerns an elderly Palestinian man in the West Bank who remembers moving the 'official' border (which was in the form of wooden stakes painted white) between Israel and (then) Transjordan in 1948 in order to ensure that his house and land were together and not divided by the border. In a similar way, the film shows how the current 'separation wall' creates difficulties for Palestinians 
and their daily lives (Usher 2006). In one scene that seems never-ending, the camera follows the large grey wall for several minutes in silence. In other scenes the futility and pointlessness of such separation is made clear. For example, an Israeli in the North of Israel feels that "there's room for everyone in this land". In a somewhat crude comparison, he likens the separation wall to his dog which keeps liaising with his neighbour's dog that is a pedigree; such illicit affairs have angered his neighbour who has built a wall to prevent it but inevitably the wall has proven to be useless and the liaison has continued.

The film stresses the role of spaces of communication which can become confrontational or therapeutic and can allow opinions to be aired. There are many examples of this in the film, ranging from examples given above to a demonstration in Lod/Lydda where people are using their voices and public space to try and achieve social justice for Arabs in the town. In another scene, Israeli peace demonstrators take to the streets to break a curfew at Nablus in the West Bank in order to take food to its residents. They cross fields and ugly, violent scenes follow in Nablus as the Israeli military tries to prevent them from doing so. The directors are also continuously shown speaking to Israelis and Palestinians, asking questions, which are often fairly deep, confrontational, thought-provoking and at times, not easily answered. For example, the following conversation at a checkpoint illustrates this.

Filmmaker: (to Israeli soldier) Is there a brain under that helmet?

Soldier: I do what the army tells me to do

Filmmaker: Do you ever think about what you do? 
Soldier: I'm not doing any harm

In another scene, one of the filmmakers asks an elderly Israeli man who fought in 'Operation Matate' (Broom) in the years leading up to 1948 whether he felt any pity towards those expelled. The man struggles with his answer but finally says "We felt pity. We're human...we did it to survive". This persistence of asking difficult questions stresses the need to do so and to use space in active ways that facilitates critical thought and imagination. It is within everyday spaces that people deal with differences; as a result, space becomes malleable, part of relationships, performances and practices. Later on in the film at the end of the second part, a family in Beit Jala in the West Bank is celebrating a wedding; it is a surreal scene as well-dressed guests make their way through rubble to a restaurant despite a curfew and road closures. This ability for Palestinians to practice 'samud' and get on with daily life has been documented (Taraki 2006; Halper 2006; Kelly 2008; Allen 2008).

\section{Geographies and spaces of hopeful-ness in Palestine-Israel?}

This paper has demonstrated the importance of analysing space within film as a means to help create a spatial politics of affect and hope within conflict situations, and therefore adds to work on the geographies of performativity, hope, film and Palestine-Israel. The analyses of films which perform space in connecting yet also complex ways have two outcomes. Firstly, they can advance more hopeful theorisations of space in PalestineIsrael and in other conflict areas and secondly, they can help create conflict resolution 
by asking audiences to imagine space in more connected, complicated ways, in turn interrogating simplistic or extreme perceptions of the Other.

There are key themes and issues which emerge in both films. These include the importance (and at times absence) of communication, ambivalence/subversion and the perseverance of everyday lives in which identities are negotiated in shared and separate spaces. The films demonstrate the need and importance of conceptualising space in more hopeful ways, despite the obvious tensions and difficulties that exist in the region. In both films, third space is constraining and enabling, hopeful and limiting, emphasising the need for geographies of everyday hopeful-ness in which feelings, emotions, bodies and experiences in and through space are important. As Curti (2008, 116) outlines: "Instead of a fight of and for negation, understanding the conflict through bodily forces of affect, emotion and memory reveals that Palestinian actions in the conflict are not primarily driven by the desire to negate Israeli bodies". The viewing of Palestinians and Israelis as separate denies the radical possibility of space and the empowerment that can be created as space is reconstituted, appropriated and made hopeful even in the bleakest of situations and realities. Geographers can therefore usefully engage with Palestinian and Israeli film and drama that attempts to use space in radical, potentially connecting ways, as a means to engage audiences to think critically about themes such as separation, Othering, power relations, history and territorial control. The paper stresses the value of creating a liminal but potentially hopeful and empowering spatial politics of affect through an analysis of performance beyond representation and borders in Palestine-Israel and other areas of conflict. 


\section{References}

Abramovich D 2005 Overcoming the cultural barriers of conflict: Dialogue between Israelis and Palestinians, Jews and Muslims, Journal of Intercultural Studies 264293 $-313$

Abdel-Malek K 2006 Rhetoric of violence and reconciliation: Arab-Jewish encounters in Contemporary Palestinian literature and film Palgrave Macmillan, Basingstoke Abdo N and Yuval-Davis N 1995 Palestine, Israel and the Zionist settler project in D K Stasiulis and N Yuval-Davis eds Unsettling settler societies: Articulations of gender, race, ethnicity and class Sage, London 291-323

Abu-Manneh B 2004 Journey toward a route in common Middle East Report 231

Abunimah A 2006 One country: A bold proposal to end the Israeli-Palestinian impasse Metropolitan Books, New York

Aitken S and Zonn L eds 1994 Place, power, situation and spectacle: A geography of film. London: Rowman \& Littlefield.

Alexander $\mathbf{L} 2005$ Is there a Palestinian cinema? The national and transnational in Palestinian film production in R L Stein and T Swedenburg eds Palestine, Israel and the politics of popular culture Duke University Press, Durham and London, 150-172 Allen L 2008 Getting by the Occupation: How violence became normal during the second Palestinian Intifada Cultural Anthropology 233 453-487

Anderson B and Fenton J 2008 Editorial introduction: Spaces of hope Space and Culture $1176-80$ 
Anderson B 2006 Transcending without transcendence: Utopianism and an ethos of hope Antipode, 384 691-710

Anzaldúa G 1999 Borderlands/La Frontera: The New Mestriza Aunt Lute Books, San Francisco

Ashcroft B 2009 Beyond the nation: Post-colonial hope The Journal of the European Association of Studies on Australia 1

Bardenstein C 2005 Cross/cast: Passing in Israeli and Palestinian cinema in R L Stein and T Swedenburg eds Palestine, Israel and the politics of popular culture Duke University Press, Durham and London, 99-126

Bowman G 2007 Israel's wall and the logic of encystation: Sovereign exception or wild sovereignty? Focaal—European Journal of Anthropology 50 127-136

Ben-Eliezer U 2007 Multicultural society and everyday cultural racism: second generation of Ethiopian Jews in Israel's 'crisis of modernization' Ethnic and Racial Studies $315935-961$

Ben-Zvi L 2006 Staging the Other Israel: the documentary theatre of Nola Chilton TDR: The Drama Review 503 T191 Fall

Bhabha H 1994 The location of culture Routledge, London

Blomley N 2007 Critical geography: anger and hope Progress in Human Geography $31153-65$

Blunt, A Bonnerjee J Lipman C Long L and F Paynter My home: text, space and performance Cultural Geographies 14 309-318 
Brenner R F 2003 Inextricably bonded: Israeli Arab and Jewish writers re-visioning culture University of Wisconsin Press

Carter S and McCormack D P 2006 Film, geopolitics and the affective logics of intervention Political Geography 25 228-245

Clifford J 1997 Routes: Travel and translation in the late twentieth century Harvard University Press, Cambridge

Cresswell T and Dixon D eds 2002 Engaging Film: Geographies of Mobility and Identity, Rowman and Littlefield, Maryland

Crouch D 2003 Spacing, performing and becoming: tangles in the mundane, Environment and Planning A 35 1945-1960.

Curti G H 2008 From a wall of bodies to a body of walls: Politics of affect | politics of memory | politics of war Emotion, Space and Society 12 106-118

Dabashi H ed 2006 Dreams of a Nation Verso, London

Dewsbury J D 2000 Performativity and the event: enacting a philosophy of difference Environment and Planning D: Society and Space 18 473-496.

Dixon D P and Grimes J 2004 On capitalism, masculinity and whiteness in a dialectical Landscape: The case of Tarzan and the Tycoon Geojournal, 59.4: 265-275

Dodds, K 2003 Licensed to stereotype: popular geopolitics, James Bond and the spectre of Balkanism Geopolitics 82 125-156

Electronic Intifada website http://electronicintifada.net/v2/article2497.shtml, last accessed $10^{\text {th }}$ November 2010 
Falah G 2003 Dynamics and patterns of the shrinking Arab Palestinian lands in Palestine Political Geography 222 179-209

Falah G 1996 The 1948 Israeli-Palestinian War and its aftermath: the transformation and de-signification of Palestine's cultural landscape, Annals of the Association of American Geographers 862 256-285

Falah G Hoy M and Sarker R 2000 Co-existence in selected mixed Arab-Jewish cities in Israel: By choice or by default? Urban Studies 374775 - 796

Fenigstein M 2007 Coming soon to a theatre near you: The Israeli-Palestinian conflict at the movies, in J Kuriansky J ed Beyond bullets and bombs: grassroots peacebuilding between Israelis and Palestinians, Westport, Praeger

Forman G and Kedar A 2004 From Arab land to 'Israeli lands': the legal dispossession of the Palestinians displaced by Israel in the wake of 1948 Environment and Planning D: Society and Space 22 809-830

Gertz N and Khleifi G 2008 Palestinian cinema: Landscape, trauma and memory Edinburgh University Press, Edinburgh

Gesser-Edelsburg A 2011 Entertainment-education: dilemmas of Israeli creators of theatre about the Israeli-Palestinian conflict in promoting peace, Journal of Peace Education 81 55-76

Gordon U 2010 Against the wall: Anarchist mobilization in the Israeli-Palestinian conflict Peace \& Change 53 412-433

Graham S 2002 Bulldozers and bombs: the latest Palestinian-Israeli conflict as asymmetric urbicide Antipode 34 642-649. 
Gregory D 2004 The colonial present: Afghanistan, Palestine, Iraq Blackwell, Oxford Gur-Ze'ev I and Pappé I 2003 Beyond the destruction of the other's collective memory. Theory, Culture and Society 201 93-108

Hallward M 2009 Creative Responses to Separation: Israeli and Palestinian Joint Activism in Bil'in Journal of Peace Research 464 541-558

Hanafi S 2009 Spacio-cide: colonial politics, invisibility and rezoning in Palestinian territory Contemporary Arab Affairs 21 106-121

Hall S 1999 Cultural identity and diaspora in S Vertovec and R Cohen eds Migration, diasporas and transnationalism Elgar, Cheltenham 299-31

Halper J 2006 A strategy within a non-Strategy: Sumud, resistance, attrition, and advocacy, Journal of Palestine Studies 35345 Open Forum

Harker C 2006 A 'historic' day and a nonhistoric day in the history of Palestine.

Environment and Planning D: Society and Space 243 317-323

Herzog H 2009 Choice as everyday politics: Female Palestinian citizens of Israel in mixed cities Int J Polit Cult Soc 22 5-21

Hutnyk J 2005 Hybridity Ethnic and Racial Studies 28179 - 102

Kalra V S Kaur R and Hutnyk J 2006 Diaspora and hybridity Sage London

Kaufman E Salem W and Verhoeven J eds 2006 Bridging the divide: Peacebuilding in the Israeli Palestinian conflict Lynne Rienner Publishers, Boulder:

Kayyal M 2006 A hesitant dialogue with 'the Other': The interactions of Arab intellectuals with Israeli Culture Israel Studies 112 54-74 
Kelly T 2008 The attractions of accountancy: Living an ordinary life during the second Palestinian Intifada Ethnography 9 351-376

Kelman H 1999 The interdependence of Israeli and Palestinian national identities: the role of the Other in existential conflicts Journal of Social Studies 55 581-600

Kuriansky J ed. 2007 Beyond bullets and bombs: grassroots peacebuilding between Israelis and Palestinians, Westport, Praeger

Lawson V 2007 Introduction: Geographies of fear and hope Annals of the Association of American Geographers 972 335-337

Lindholm Schulz H 2003 The Palestinian diaspora: Formation of identities and politics of homeland Routledge, London.

Long J 2009 Rooting diaspora, reviving nation: Zionist landscapes of Palestine-Israel Trans Inst Br Geogr 34 61-77

Long J 2006 Border anxiety in Israel-Palestine Antipode 381 107-127

Lukinbeal C 2004 The map that precedes the territory: An introduction to essays in cinematic geography GeoJournal 59 247-251

Maoz I 2011 Does contact work in protracted asymmetrical conflict? Appraising 20 years of reconciliation-aimed encounters between Israeli Jews and Palestinians Journal of Peace Research 48 115-125

Masalha N 2008 Remembering the Palestinian Nakba: Commemoration, oral history and narratives of memory Holy Land Studies 72 123-156 
Mavroudi E 2010 Imagining a shared state in Palestine-Israel Antipode 4211 - 236

Menkel-Meadow C and Nutenko I 2009 On teaching the next generation: Creating new peace processes in the Middle East Negotiation Journal 254 569-686

Mitchell K 1997 Different diasporas and the hype of hybridity Environment and Planning D 14 487-499

Monterescu D and Rabinowitz D eds 2007 Mixed towns, trapped communities: historical Narratives, spatial dynamics, gender relations and cultural encounters in Palestinian-Israeli towns Ashgate, London

Nagar R 2002 Women's theatre productions and redefinitions of public, private and politics in North India Acme 1 55-72.

Newman D 2008 The formation of national identity in Israel/Palestine: the construction of spatial knowledge and contested territorial narratives in N. Slocum-Bradley (ed) Promoting conflict or peace through identity Ashgate, London

Newman D 2006 The resilience of territorial conflict in an era of globalization in M Kahler and BF Walter eds Territoriality and conflict in an era of globalization Cambridge University Press, Cambridge

Pallister-Wilkins P 2009 Radical ground: Israeli and Palestinian activists and joint protest against the wall Social Movement Studies $84393-407$

Pappé I 2004 A history of modern Palestine: One land, two peoples Cambridge University Press, Cambridge

Phillips R ed. 2009 Muslim spaces of hope Zed Books, London 
Pile S 2010 Emotions and affect in recent human geography Transactions of the Institute of British Geographers 35 5-20

Portugali J 1993 Implicate relations: Society and space in the Israeli-Palestinian conflict Springer, New York

Pratt G and Johnston C 2007 Turning theatre into law and other spaces of politics, Cultural Geographies 141 92-113.

Rabinowitz D and Abu-Baker K 2005 Coffins on our shoulders: The experience of the Palestinian citizens of Israel University of California Press, Berkeley

Raz G 2005 Actuality of banality: Eyal Sivan's The Specialist in context Shofar: An Interdisciplinary Journal of Jewish Studies 24 14-21

Said E 2001 The End of the Peace Process: Oslo and After Granta Books, London

Said E 1986 After the last sky: Palestinian lives Vintage, London

Said E 1978 Orientalism Penguin, Harmondsworth

Scham P 2000 Arab-Israeli research cooperation, 1995-1999: An analytical study Middle East Review of International Affairs 43

Schnell I 2001 Introduction: changing territorial concepts in Israel - from besieged nation building to globalisation GeoJournal 533 213-217

Schulz M 2008 Reconciliation through education - experiences from the IsraeliPalestinian conflict Journal of Peace Education 51 33-48

Shalhoub-Kevorkian N 2006 Negotiating the present, historicizing the future:

Palestinian children speak about the Israeli separation wall American Behavioral Scientist 49 1101-1124 
Shamir J and Shikaki K 2002 Determinants of Reconciliation and Compromise Among Israelis and Palestinians Journal of Peace Research 392 185-202

Shohat E 1989 Israeli cinema: East/West and the politics of representation University of Texas Press, Austin

Stephan C W Hertz-Lazarowitz R Zelniker T and Stephen W G 2004 Introduction to improving Arab-Jewish relations in Israel: theory and practice in coexistence education Journal of Social Studies $602237-252$

Taraki L 2006 Living Palestine: Family survival, resistance and mobility under occupation Syracuse University Press, Syracuse

Thrift, N 2004 Intensities of feeling: towards a spatial politics of affect. Geografiska Annaler 86B 1 157-178

Thrift N and Dewsbury JD 2000 Dead geographies and how to make them live Environment and Planning D: Society and Space 18 411-432

Tilley V 2005 The one-state solution: A breakthrough for Peace in the Israeli Palestinian deadlock Manchester University Press, Manchester

Usher G 2006 The wall and the dismemberment of Palestine Race \& Class 47 3 9-30

Wallach Y 2011 Trapped in mirror-images: The rhetoric of maps in Israel/Palestine Political Geography 30 358-369

Walsh N R Kuriansky J and Toppano L 2007 Kites fly for peace: Staging PalestinianIsraeli peace in J Kuriansky ed Beyond bullets and bombs: grassroots peacebuilding between Israelis and Palestinians, Westport, Praeger 
Yacobi H 2008a Architecture, orientalism, and identity: The politics of the Israeli-Built environment Israel Studies 13 94-118

Yacobi H 2008b Irregular migration to Israel CARIM analytical and synthetic notes $2008 / 63$

Yerushalmi D 2007 From a Transient to a Resident The Acco Festival of Alternative Israeli Theatre, 2001-2004 TDR: The Drama Review 514 Winter

Yiftachel 02006 Land and identity politics in Israel/Palestine University of Pennsylvania Press, Philadelphia

Yuval-Davis N 2007 Zionism, anti-Semitism and the struggle against racism Soundings $36122-133$

Zureik E Lyon D and Abu-Laban Y 2010 Surveillance and control in Israel/Palestine: Population, territory and power Routledge, London 